\title{
ROSE-WAALER TEST USING A RAPIDLY PREPARED SERUM FRACTION
}

\author{
DOUGLAS WHILLANS AND ANDOR FISCHMAN \\ Central Laboratory, Auckland Hospital, Auckland, New Zealand
}

The use of a serologically active fraction of serum in parallel with whole serum, in testing for the sheep cell agglutinating factor in rheumatoid arthritis, was suggested by Svartz and Schlossmann (1953) and by Ziff, Brown, Badin, and McEwen (1954). Claims of higher sensitivity and specificity have been re-emphasized in more recent publications (Ziff, Brown, Lospalluto, Badin, and McEwen, 1956; Svartz and Schlossmann, 1957). Since 1956, sheep cell agglutination tests have been performed in this laboratory by Ziff's method, using absorbed serum, euglobulin fraction, and inhibition titres as criteria (Rose and Whillans, 1957). This experience confirms the view of Hess (1956) that, while the technique is laborious, it is not outside the scope of a laboratory doing routine serological tests.

Although the exact nature of the rheumatoid agglutinating factor is not yet elucidated, it is usually considered to migrate in an electrical field mainly with the gamma globulins (Lamont-Havers, 1955; Svartz and Schlossmann, 1955; Lospalluto and Ziff, 1956). Thulin (1955) considered it to be distributed over the faster moving gamma and beta globulins, while Heller, Kolodny, Lepow, Jacobson, Rivera, and Marks (1955) classified it mainly as a beta-lipoprotein. Recently Franklin, Kunkel, Müller-Eberhard, and Holman (1957) presented evidence from ultracentrifugal studies for a fast moving gamma globulin being responsible for the serological activity in rheumatoid arthritis and a similar view has been put forward by Svartz (1957).

The preparation of the euglobulin fraction used in Ziff's method is a time consuming process, so that a search was made for a simpler method of preparing the active fraction. In view of the above it appeared to us that a gamma globulin fraction would be desirable. Serum fractions consisting mainly of gamma globulins can be prepared, using ammonium sulphate for salting out, by prolonged standing. However, the rapid and simple method of
Wolfsohn, Cohn, Calvary, and Ichiba (1948) gives a complete precipitate in less than one hour, and when haemagglutination titres using this fraction and Ziff's euglobulin showed good parallelism it was decided to compare the two fractions further.

\section{Methods}

Preparation of the Euglobulin Fraction (EU)

This was carried out according to the method of Ziff and others (1954). The precipitate was dissolved in physiological saline to give a $1: 4$ dilution compared with the original serum.

\section{Preparation of the Ammonium Sulphate Fraction (AS)}

$9.6 \mathrm{ml}$. of a solution containing $193 \mathrm{~g}$. ammonium sulphate and $40 \mathrm{~g}$. sodium chloride per litre was pipetted into a $15-\mathrm{ml}$. centrifuge tube, and $0.4 \mathrm{ml}$. of the inactivated and absorbed serum layered on top. The two components were then mixed by slow, repeated inversion for about 2 minutes. The tube was now corked and centrifuged at 2,500-3,000 rpm in an M.S.E. Major centrifuge for 30 minutes, the supernatant poured off, and the tube allowed to stand in an inverted position on filter paper for a few minutes. The precipitate was then dissolved in $1.6 \mathrm{ml}$. physiological saline with the aid of a glass rod. This also gave a $1: 4$ dilution compared with the original serum and this was ready for use in the haemagglutination test.

\section{Sensitized Sheep Cells}

The sheep cells were collected in Alsever's solution containing $0 \cdot 1$ per cent. streptomycin sulphate and standardized to 0.5 per cent. working suspension, using an EEL nephelometer and a method similar to that previously described for complement-fixation tests (Whillans, 1950). The haemolysin was prepared according to the method of Sawyer and Bourke (1946) and its basic agglutinating titre (BAT) determined, using dilutions of haemolysin ranging from $1: 100$ to $1: 2,000$.

To $0.5 \mathrm{ml}$. of each dilution, $0.5 \mathrm{ml}$. of 0.5 per cent. sheep cell suspension was added. After the tubes had been kept overnight at $4^{\circ} \mathrm{C}$., the cell pattern in the bottom of the tube was read by holding it over a concave mirror while illuminating it from the side with a lamp. 
In high concentration of haemolysin, the cells form into a tightly patterned clump, often showing "chinese characters" in the centre. As the haemolysin concentration decreases, the cells fill the bottom of the tube, and as the concentration decreases still further, the cells form a pattern and then a button. The end point is shown by that tube containing a pattern which has in its next higher dilution a tube containing a button. This method of reading has proved much easier than that of Ziff and others (1956), and in our hands is more reproducible.

Using the information thus derived, cells were then sensitized by adding an equal amount of the appropriate dilution of haemolysin in 0.9 per cent. saline at $37^{\circ} \mathrm{C}$. to 0.5 per cent. sheep cells in 0.9 per cent. saline also at $37^{\circ} \mathrm{C}$., so that the final cell suspension contained either $\frac{1}{4}$ or $\frac{1}{2}$ BAT of haemolysin. After the mixed suspension had been kept at $37^{\circ} \mathrm{C}$. for 30 minutes, the sensitized cells were ready for use.

\section{Titration of Euglobulin (EU) and Ammonium Sulphate} Fraction (AS)

Starting with a $1: 4$ dilution as prepared above, serial twofold dilutions of EU and AS fractions were prepared in 0.9 per cent. saline using $0.5 \mathrm{ml}$. volumes. To these were added $0.5 \mathrm{ml}$. of the appropriately sensitized cells. After standing overnight at $4^{\circ} \mathrm{C}$., the cell pattern was read as above. The first tube represented a titre of $1: 16$ calculated as the final dilution.

\section{Inhibition}

This was carried out according to the method of Ziff and others (1954), but using both EU and AS fractions in twofold dilution series, the titre being read as above.

\section{Results}

\section{Comparisons between EU and AS Titres}

Simultaneous haemagglutination tests were performed on EU and AS fractions prepared from a total of 280 sera. These had been sent to us for a routine performance of the Rose-Waaler test. Clinical diagnoses were not considered in this comparison. The diagnostic value of haemagglutination tests on serum fractions has been summarized by Ziff (1957).

Normal levels were established on the basis of haemagglutination tests on fractions derived from pooled donors' sera and on previous experience with fractions tested routinely.

(1) Preliminary Series. Sensitizer 1:2 Basic Agglutinating Titre.-In this series fifty fractions were compared. Of these, 31 sera had a raised titre and seventeen had a normal titre in both fractions. This gave an agreement of 96 per cent. In two cases ( 4 per cent.) the EU had a titre one tube above the normal level, while the corresponding AS was within normal limits.
(2) Second Series. Sensitizer 1:4 Basic Agglutinating Titre.-In this series, a reduction of haemolysin was tried, as it was thought desirable to keep the normal titre as low as possible. 94 fractions were compared, of which 58 showed a raised level and 32 a normal level in both fractions. In four cases ( $4 \cdot 3$ per cent.), the AS had a level of $1: 32$ (with the normal titre established at $1: 16$ or less) and the corresponding EU was within normal limits. Comparing titres, 45 fractions showed identical results, while 46 showed a one-tube difference and three a two-tube difference. We should, however, consider a one-tube difference to be within the experimental error of the method. This level of sensitization caused not only a slight drop in titre, but in three cases a reduction of sensitivity by shifting values from raised to normal range (e.g. Case 8, Table I).

(3) Third Series. Sensitizer 1:2 Basic Agglutinating Titre.-A further 136 sera were compared using $1: 2$ BAT. A normal titre of $1: 32$ or less was established using this level of sensitivity.

Of these sera, 88 showed raised titres and 43 normal titres in both fractions. In five cases $(3 \cdot 7$ per cent.), one fraction showed a titre one tube above the normal limit while the other fraction waso within the normal limit (four AS and one EU) Comparing titres, 62 fractions had identical titres 64 showed a one-tube difference, and $10(7 \cdot 4$ per? cent.) showed a two-tube difference (Table I).

$$
\text { TABLE I }
$$

EXAMPLES OF HAEMAGGLUTINATION TITRES ON FRACTIONS AND EFFECT OF CELL SENSITIZING DOSE

\begin{tabular}{|c|c|c|c|c|}
\hline \multirow{3}{*}{ Sample } & \multicolumn{4}{|c|}{ Basic Agglutinating Titre } \\
\hline & \multicolumn{2}{|c|}{$1: 2$} & \multicolumn{2}{|c|}{$1: 4$} \\
\hline & $\begin{array}{c}\text { Ammonium } \\
\text { Sulphate }\end{array}$ & Euglobulin & $\begin{array}{c}\text { Ammonium } \\
\text { Sulphate }\end{array}$ & Euglobulin \\
\hline $\begin{array}{r}1 \\
2 \\
3 \\
4 \\
5 \\
6 \\
7 \\
8 \\
9 \\
10\end{array}$ & $\begin{array}{r}16,384 \\
2,048 \\
1,024 \\
1,024 \\
256 \\
128 \\
128 \\
64 \\
32 \\
32\end{array}$ & $\begin{array}{r}32,768 \\
2,048 \\
1,024 \\
512 \\
128 \\
128 \\
64 \\
64 \\
16 \\
32\end{array}$ & $\begin{array}{r}4,096 \\
2,048 \\
512 \\
256 \\
256 \\
64 \\
128 \\
16 \\
16 \\
16\end{array}$ & $\begin{array}{r}4,096 \\
1,024 \\
256 \\
128 \\
128 \\
64 \\
64 \\
16 \\
\text { Under } 16 \\
\text { Under } 16\end{array}$ \\
\hline Normal & \multicolumn{2}{|c|}{32 or less } & \multicolumn{2}{|c|}{16 or less } \\
\hline
\end{tabular}

(4) All Series considered Together.-In a total of 280 comparisons between EU and AS titres, 96.1 per cent. showed agreement, being either normal or raised in both fractions. In 3.9 per cent., one fraction had a raised titre while the other was normal (eight AS, three EU). However, in each 
of these cases the titre was only one tube above the level considered to be the upper limit of normal, and thus of little significance (Table II).

TABLE II

COMPARISON OF HAEMAGGLUTINATION TESTS ON AMMONIUM SULPHATE AND EUGLOBULIN FRACTIONS IN 280 CASES

\begin{tabular}{|c|c|c|c|c|}
\hline \multicolumn{3}{|c|}{ Result } & No. & $\begin{array}{l}\text { Per } \\
\text { cent. }\end{array}$ \\
\hline \multirow[t]{2}{*}{ Agreement } & $\begin{array}{l}\text { Both AS and EU raised } \\
\text { Both AS and EU normal }\end{array}$ & $\begin{array}{l}\cdots \\
\cdots\end{array}$ & $\begin{array}{r}177 \\
92\end{array}$ & \\
\hline & Total & $\ldots$ & 269 & $96 \cdot 1$ \\
\hline $\begin{array}{l}\text { Dis- } \\
\text { agreement }\end{array}$ & $\begin{array}{l}\text { EU normal, AS one tu } \\
\text { normal } \\
\text { AS normal, EU one tu } \\
\text { normal } \ldots \\
\text { One fraction normal, the } \\
\text { than one tube above no }\end{array}$ & $\begin{array}{l}\text { above } \\
\ldots \text { above } \\
\text { her more } \\
\text { mal } \ldots\end{array}$ & $\begin{array}{l}8 \\
3 \\
0\end{array}$ & $\begin{array}{l}2 \cdot 8 \\
1 \cdot 1 \\
0\end{array}$ \\
\hline Tota & 1 Cases .. & $\ldots$ & 280 & 100 \\
\hline
\end{tabular}

\section{Importance of Preliminary Absorption with Sheep Cells}

A comparison was made between titres using AS fractions before and after absorption with sheep cells, as the elimination of this step would simplify the procedure. In a small series of twenty fractions, four showed a two-tube difference and ten a onetube difference, and six were identical. The negative control with unsensitized sheep cells showed definite agglutination in four fractions and doubtful agglutination in a further four. The positivity of the test was affected in three cases (15 per cent.) (Table III).

\section{Inhibition Test}

The inhibition test was performed simultaneously on the EU and AS fractions of 100 sera; 51 showed inhibition and 41 absence of inhibition in both fractions, while eight showed disagreement. Of the latter, five AS and three EU fractions showed absence of inhibition while inhibition was present in the corresponding fraction.

\section{Discussion}

The method of Wolfsohn and others (1948) for the estimation of gamma globulin has been adapted for the production of a serologically active fraction from the serum of cases of rheumatoid arthritis. This avoids a step involving 48 hours dialysis and is therefore more suited to routine use than is Ziff's euglobulin fraction. In comparison with the latter, it showed practically identical serological activity, the discrepancies being confined to a few cases in the doubtful range just above normal.

An electrophoretic analysis of fifteen sera and their corresponding ammonium sulphate fractions showed the AS fraction to consist mainly of gamma globulin with about 6-15 per cent. beta globulin, and to include almost the whole of the gamma globulin of the original serum. This finding is of the same order as that of Wolfsohn and others (1948).

The addition of sodium chloride to the ammonium sulphate solution as used above produces a complete precipitate of gamma globulin in less than an hour, compared with the long standing required when ammonium sulphate alone is used. The ease with which such a precipitate may be produced and used to estimate gamma globulins has been shown in previous viscometric studies (Fischman, 1957). It might be thought that the presence of residual salts would interfere with the haemagglutination reaction unless the precipitate was dialysed to reduce the ammonium sulphate and sodium chloride concentration, but results have shown this to be unnecessary. Further, comparative estimations of the agglutinating titre of haemolysin for sheep cells, using 0.9 per cent. saline without and with ammonium sulphate in the concentration found in the AS fraction diluted $1: 8$ as in the first tube of the test, showed no difference in agglutinating titre.

There is no agreement in the literature on the sensitizing dose of haemolysin. Thus, while Ziff and others (1954) used 1:2 BAT for their whole serum and euglobulin titres and 1:20 BAT for their inhibition tests, Scott (1952) and Gibson and Ling (1956) sensitized with 1:4 BAT, Heller,

\footnotetext{
TABLE III
}

HAEMAGGLUTINATION TITRES BEFORE AND AFTER ABSORPTION WITH SHEEP CELLS IN TWENTY AMMONIUM SULPHATE FRACTIONS

\begin{tabular}{|c|c|c|c|c|c|c|c|}
\hline \multicolumn{4}{|c|}{ Before Absorption } & \multicolumn{4}{|c|}{ After Absorption } \\
\hline \multicolumn{2}{|c|}{ Haemagglutination } & \multicolumn{2}{|c|}{ Unsensitized Cell Control } & \multicolumn{2}{|c|}{ Haemagglutination } & \multicolumn{2}{|c|}{ Unsensitized Cell Control } \\
\hline Raised & Normal & Positive & Doubtful & Raised & Normal & Positive & Doubtful \\
\hline 16 & 4 & 4 & 4 & 13 & 7 & 0 & 0 \\
\hline
\end{tabular}


Jacobson, Kolodny, and Kammerer (1954) with $1: 20$ BAT, and Heller and others (1955) with $1: 10$ BAT. In our experience, $1: 2$ BAT has seemed preferable, but from batch to batch of haemolysin the appropriate amount has varied between $1: 2$ and $1: 4$ BAT, a BAT under $1: 4$ showing a considerable loss in sensitivity.

Absorption with Sheep Cells.-Craig, Kerby, and Persons (1957) suggested that, when a euglobulin fraction is used to test for haemagglutination, preliminary absorption with sheep cells may be omitted. No data were, however, presented to show whether these authors found an absence of heterophile antibodies in all samples, or whether they thought that the effect of their presence on the titre was negligible. In the small series tested in the present study, an appreciable effect on the titre was shown in 15 per cent. Preliminary absorption of the inactivated sera with sheep cells was therefore continued.

Other Methods for preparing Serologically Active Fractions.-While the cold precipitation method of Svartz and Schlossmann (1955) is somewhat simpler than the Ziff fractionation, it requires 48 hours chilling. Craig and others (1957) have recently described a rapid method for the production of a euglobulin fraction, using dilute hydrochloric acid. Although fast, it seems somewhat less convenient than the AS method, since it requires refrigeration and the use of a refrigerated centrifuge. In contrast, all steps in the ammonium sulphate precipitation can be carried out at room temperature within an hour.

Several methods have been proposed to replace the sheep cell haemolysin with FII globulin, in carrying out the titration either with sheep cells or with latex or other particles. Bartfeld, Mahood, and Hartung (1958), while emphasizing that with latex particles the procedure is simplified, test the serum only, as they consider the more sensitive fraction techniques unsuitable for routine diagnostic use because of their length and complexity. The present study suggests that, while the above remarks may apply to the inhibition technique and to agglutination techniques on fractions of Ziff and others or of Svartz and others, the AS fractionation is both simple and rapid, may be easily adapted for routine use, and would seem worthwhile for a trial in the FII technique.

Inhibition.-The AS fraction may also be used to perform the inhibition test as proposed by Ziff and others (1954) on the euglobulin fraction. These authors claimed higher specificity for the inhibition test than for the fraction haemagglutination titre, but in general it was found impossible to reproduce this higher specificity, irrespective of the fraction used, and Ziff himself says that his test is difficult to adapt for routine use (Ziff, 1957). No attempt was made in the present study to evaluate the inhibition test as a routine practical procedure.

One technical difficulty seems to lie in the adjustment of the proper dilution of the known positive serum used. According to Ziff and others (1954), the positive serum is agglutinated with sheep cells sensitized with 1:20 BAT haemolysin, and oneeighth of this titre gives the dilution to be used in the inhibition titration. Using these criteria with one batch of positive serum, it was found that complete lack of inhibition occurred somewhat less frequently than a positive fraction titre in cases diagnosed as rheumatoid arthritis. A new batch of positive serum, however, which had the same titre as the previous one and was used in the same dilution, was not inhibited by any serum, including negative controls. A dilution five times greater than the previous one had to be used to obtain comparable results. This applied whether AS or EU fractions were used. This dilution gave higher sensitivity and specificity than was obtained by using the previous serum, and gave a better correlation with the fraction haemagglutination titre. Any attempto to increase the sensitivity, however, resulted in absence of inhibition in normal control sera. Itō seems that one has to decide on the level to be used in an arbitrary fashion. We attempted to keep our normal level at $1: 32$.

\section{Summary}

A simple method of producing a gamma globulin fraction of whole serum for use in the Rose-Waaler test is described. It is produced in less than an hour at room temperature, and is suitable for demonstrating both the haemagglutination and inhibition factors.

A comparison between 280 simultaneous haemagglutination tests on this fraction and the euglobulin fraction described by Ziff and associates gave similar raised or normal results in 96.1 per cent. of cases. In the remainder, the euglobulin fraction was normal with the ammonium sulphate fraction one doubling dilution above normal in $2 \cdot 8$ per cent., of cases, and the ammonium sulphate fraction was normal with the euglobulin fraction one doubling dilution above normal in $1 \cdot 1$ per cent. of cases.

Inhibition titres performed on both fractions according to the method of Ziff and his associates gave identical results in 92 per cent. of cases.

Some problems relating to the level of sensitization 
of sheep cells with haemolysin and the use of a routine inhibition test are discussed.

This ammonium sulphate precipitated fraction offers a rapid and convenient alternative to lengthy methods requiring either dialysis or cold precipitation for the preparation of material for the RoseWaaler test.

\section{REFERENCES}

Bartfeld, H., Mahood, E., and Hartung, E. F. (1958). Ann. rheum. Dis., 17,83

Craig, H. W., Kerby, G. P. and Persons, E. L. (1957). J. Lab. clin. Med., 49, 635 .

Fischman, A. (1957). J. N.Z. Ass. Bact., 12, 30.

Franklin, E. C., Kunkel, H. G., Müller-Eberhard, H. J., and Holman, H. R. (1957). Ann. rheum. Dis., 16, 315 .

Gibson, H. J., and Ling, N. R. (1956). Ibid., 15, 246.

Heller, G. Jacobson, A. S. Kolodny, M. H., and Kammerer, W. H. (1954). J. Immunol., 72, 66.

-, Kolodny, M. H., Lepow, I. H., Jacobson, A. S., Rivera, M. E., and Marks, G. H. (1955). Ibid., 74, 340.

Hess, E. V. (1956). Brit. med. J., 1, 1426.

Lamont-Havers, R. W. (1955). Proc. Soc. exp. Biol. (N.Y.), 88, 35.

Lospalluto, J., and Ziff, M. (1956). Ann. rheum. Dis., 15, 382.

Rose, B. S., and Whillans, D. (1957). N.Z. med.J., 56, 525 .

Sawyer, H. P., and Bourke, A. R. (1946). J. Lab. clin. Med., 31, 714.

Scott, F. E. T. (1952). Lancet, 1, 392.

Svartz, N. (1957). Ann. rheum. Dis., 16, 441

and Schlossmann, K. (1953). Acta med. scand., 146, 313

- (1955). Ann. rheum. Dis., 14, 191. (1957). Ibid., 16, 73.

Thulin K E (1955). Acta rheum, scand., 1, 22.

Ziff, M. (1957). J. chron. Dis., 5, 644.

Brown, P., Badin, J., and McEwen, C. (1954). Bull. rheum. Dis., 5,73 .

J. Med., $20,500$.

Whillans, D. (1950). J. clin. Path., 3, 56

Wolfson, W. Q., Cohn, C., Calvary, E., and Ichiba, F. (1948). Amer. J. clin. Path., 18, 723.

Réaction de Rose-Waaler à l'aide d'une fraction sérique rapidement préparée

\section{RÉSUMÉ}

On décrit un simple procédé pour préparer la fraction globuline gamma du sérum complet pour la réaction de Rose-Waaler. On la produit en moins d'une heure à la température ambiante et elle se prête à décéler aussi bien les facteurs hémagglutinants que les inhibiteurs.

En comparant 280 réactions d'hémagglutination simultanées à l'aide de cette fraction et à l'aide de la fraction d'euglobine selon Ziff et col., on obtint les mêmes résultats, élevés ou normaux, dans $91,1 \%$ des cas. Dans le reste, la réaction à l'aide de la fraction d'euglobine fut normale tandis que la réaction à l'aide de la fraction précipité par le sulfate d'ammonium fut une dilution double au dessus de la normale dans $2,8 \%$ des cas; l'inverse eut lieu dans $1,1 \%$ des cas.

Les réactions d'inhibition avec les deux fractions, selon la méthode de Ziff et col., donnèrent des résultats identiques dans $92 \%$ des cas.

On discute quelques problèmes concernant le degré de sensibilisation des globules de mouton avec de l'hémolysine et l'emploi régulier de la réaction d'inhibition.

La fraction précipité par le sulfate d'ammonium offre une alternative commode à des procédés laborieux demandant soit une dialyse, soit une précipitation au froid, pour préparer du matériel pour la réaction de Rose-Waaler.

\section{Reacción de Rose-Waaler empleando una fracción sérica rapidamente preparada}

\section{SUMARIO}

Se describe un simple método de preparar la fracción globulina gama del suero completo para la reacción de Rose-Waaler. Esta fracción se obtiene en menos de una hora en la temperatura embiente y se puede emplear para evidenciar tanto los factores hemaglutinantes como inhibidores.

Al comparar 280 reacciones de hemaglutinación simultáneas con esta fracción y con la fracción de euglobina, según el modo de Ziff y col., se obtuvieron cifras parecidas, altas o normales, en un $91 \%$ de los casos. En los demás, la reacción con la fracción de euglobina fué normal mientras que la reacción con la fracción precipitada por el sulfato de amonio fué una doble dilución por encima de lo normal en un $2,8 \%$ de los casos; el resultado fué inverso en un $1,1 \%$ de los casos.

La reacción de inhibición con ambas fracciones, según el método de Ziff y col., dió resultados idénticos en un $92 \%$ de los casos.

$\mathrm{Se}$ discuten ciertos problemas respecto al grado de sensibilización de los glóbulos de oveja con hemolisina y el empleo regular de la reacción de inhibición.

La fracción precipitada por el sulfato de amonio ofrece una alternativa útil a los procedimientos fastidiosos que exigen sea una dialisis sea precipitación por el frío en la preparación del material para la reacción de RoseWaaler. 